\title{
ASUPAN PROTEIN DAN ASAM LEMAK OMEGA 6 BERLEBIH SEBAGAI FAKTOR RISIKO KEJADIAN OBESITAS PADA ANAK SEKOLAH DASAR DI SEMARANG
}

\author{
Rizki Khoirur Rachmawati ${ }^{1}$, Martha Ardiaria ${ }^{1}$, Deny Yudi Fitranti ${ }^{1}$ \\ ${ }^{1}$ Departemen Ilmu Gizi, Fakultas Kedokteran, Universitas Diponegoro \\ Jln. Prof. H. Soedarto, SH., Semarang, Telp (024) 76402881, Email : gizifk@ undip.ac.id
}

\begin{abstract}
Background: Obesity is a multifactoral condition characterized by excessive body fat accumulation. Childhood obesity is a serious problem that continue into adulthood and become a risk of degenerative diseases in the future. High protein intake in children aged 10-12 years old in Central Java $(113,1 \%)$ and change pattern consumption from Western pattern consumption that is high omega 6 fatty acid cause obesity in elementary school children.

Methods: Design of the study was case-control with 66 children aged 10-12 years divided into 2 groups, obesity and normal. This research was conducted at Pekunden Elementary School. Datas collected were protein, fiber, omega-3 fatty acid and omega-6 fatty acid intake as independent variables, while energy, carbohydrate and physical activity as confounding variables. The food intake data was obtained by using Semi Quantitative Food Frequency Questionnaire, and physical activity was obtained using the Physical Activity Questionnaire for Older Children. Datas were analyzed by Chi-Square test.

Results: Mean of protein and omega- 6 fatty acid intake in the obesity group was higher $(100.7 \pm 23.48$; $159.6 \pm 43.49)$ than the normal group $(81.4 \pm 26.13 ; 141.5 \pm 68.09)$. There were an association between excessive protein and omega- 6 fatty acid intake toward obesity, where subjects with excessive protein intake had 4.81 times higher risk for being obese $(p=0,003)$ and subjects with excessive intake of omega-6 fatty acid had 5.81 times higher risk for being obese among elementary school children $(p=0,02)$.
\end{abstract}

Conclusion: Excessive protein and omega-6 fatty acid intake is a risk factors of obesity among elementary school children.

Keywords: protein, omega-6 fatty acid, elementary school children, obesity

\begin{abstract}
ABSTRAK
Latar Belakang: Obesitas adalah kondisi multifaktoral yang ditandai dengan akumulasi lemak berlebih dalam tubuh. Obesitas pada usia sekolah merupakan masalah serius yang berlanjut hingga usia dewasa dan dapat menimbulkan risiko penyakit degeneratif. Tingginya asupan protein pada anak usia 10-12 tahun di Jawa Tengah (113,1\%) dan terjadi perubahan pola konsumsi dari pola konsumsi dunia barat yaitu tingginya asam lemak omega 6 menyebabkan terjadinya obesitas pada anak sekoah dasar.

Metode: Desain penelitian case control dengan 66 anak usia 10-12 tahun yang dibagi dalam 2 kelompok yaitu obesitas dan normal. Penelitian ini dilakukan di SDN Pekunden. Data yang diteliti meliputi asupan protein, serat, asam lemak omega 3 dan asam lemak omega 6 sebagai variabel bebas, serta asupan energi, karbohidrat, lemak dan aktivitas fisik sebagai variabel perancu. Data asupan makan diperoleh melalui kuesioner Semi Quantitative Food Frequency Questionnaire dan data aktivitas fisik diperoleh dari The Physical Activity Questionnaire for Older Children. Analisis data menggunakan uji Chi Square.

Hasil: Rerata asupan protein dan asam lemak omega 6 pada kelompok obesitas lebih tinggi $(100,7 \pm 23,48 ; 159,6 \pm 43,49)$ daripada kelompok normal $(81,4 \pm 26,13 ; 141,5 \pm 68,09)$. Terdapat hubungan antara asupan protein dan asam lemak omega 6 berlebih dengan kejadian obesitas pada anak sekolah dasar, dimana subjek dengan asupan protein berlebih memiliki 4,81 kali lebih besar berisiko obesitas $(p=0,003)$ dan subjek dengan asupan asam lemak omega 6 berlebih memiliki 5,81 kali lebih besar berisiko obesitas pada anak sekolah dasar $(p=0,02)$.

Simpulan: Asupan protein dan asam lemak omega 6 berlebih merupakan faktor risiko terhadap kejadian obesitas pada anak sekolah dasar.
\end{abstract}

Kata kunci: protein, asam lemak omega 6, anak sekolah dasar, obesitas

\section{PENDAHULUAN}

Obesitas didefinisikan sebagai kondisi dengan akumulasi lemak berlebih dalam jaringan adiposa yang dapat memengaruhi kesehatan dan dapat menimbulkan risiko masalah kesehatan. ${ }^{1,2}$ Obesitas pada usia sekolah dasar merupakan masalah serius yang berlanjut hingga usia dewasa dan dapat menimbulkan risiko penyakit degeneratif., ${ }^{2,3}$ Kriteria obesitas untuk anak usia 5-18 tahun yaitu dengan nilai Z-score IMT/U >2 SD. Riset Kesehatan Dasar 2013 menunjukkan prevalensi obesitas pada anak usia 6-12 tahun di Indonesia sebesar 18,8\%. ${ }^{4}$ Prevalensi 
tersebut mengalami peningkatan dari Tahun 2010 yaitu sebesar 9,2\%. ${ }^{5}$ Sedangkan Prevalensi obesitas pada anak usia 6-12 tahun di Provinsi Jawa Tengah pada Tahun 2013 sebesar 18\%. ${ }^{4}$ Prevalensi tersebut mengalami peningkatan dari Tahun 2010 yaitu sebesar $10,9 \% .^{5}$ Berdasarkan penelitian yang pernah dilakukan di Sekolah Dasar Semarang pada Tahun 2016 terdapat $24,7 \%$ anak sekolah dasar mengalami obesitas dari total keseluruhan 149 anak. $^{6}$

Konsumsi protein pada anak usia 5-12 tahun di Jawa Tengah sebesar 50,8 gr per hari yaitu $113,1 \%$ tergolong lebih dari kebutuhan. ${ }^{7}$ Kurangnya konsumsi buah dan sayur pada anak usia 5-12 tahun sebesar 96,5\%. ${ }^{8}$ Sedangkan proporsi anak usia 5-12 tahun di Jawa Tengah dalam konsumsi ikan yaitu $53,6 \%$ sebesar 70,7 gr per hari termasuk dalam kategori kurang. ${ }^{7}$ Obesitas dapat terjadi karena beberapa faktor, diantaranya adalah asupan makan berlebih dan kemajuan teknologi yang menyebabkan anak menjadi malas untuk melakukan aktivitas fisik. ${ }^{3,9}$ Obesitas dapat dipengaruhi oleh beberapa asupan, diantaranya adalah asupan protein, serat, asam lemak omega 3 dan asam lemak omega 6 .

Asupan protein pada masa anak-anak memiliki dampak penting pada pertumbuhan dan perkembangan. ${ }^{10,11}$ Konsumsi protein secara berlebih, protein sel akan dipecah menjadi asam amino. Pemecahan protein menjadi asam amino akan diubah menjadi asetil KoA melalui proses deaminasi yang terjadi di hati. Asetil Ko-A yang terbentuk akan dipakai untuk menghasilkan asam lemak yang berperan dalam pembentukan sel-sel adiposa. Hal inilah yang menyebabkan kenaikan jaringan lemak yang berimbas pada kenaikan berat badan dan akhirnya terjadi obesitas. ${ }^{12}$

Obesitas juga dikaitkan dengan asupan serat. Konsumsi serat dapat bermanfaat untuk mengendalikan konsumsi energi dan menurunkan berat badan. ${ }^{9}$ Serat merupakan polisakarida yang terdapat pada tumbuhan yang tidak dapat dicerna oleh enzim pencernaan. Mengkonsumsi makanan yang mengandung serat larut dapat memperlambat pengosongan lambung serta membantu mengatur asupan makan dengan meningkatkan rasa kenyang. ${ }^{9,13}$ Makanan yang mengandung serat dapat berasal dari buah-buahan, sayuran dan biji-bijian. ${ }^{14}$

Peningkatan risiko terjadinya obesitas dapat dikaitkan juga dengan konsumsi asam lemak omega 6 dan asam lemak omega 3. Asam lemak omega 6 dan asam lemak omega 3 merupakan asam lemak tidak jenuh rantai ganda yang bersifat esensial dan tidak dapat diproduksi oleh tubuh. Sumber asam lemak omega 6 terdiri dari daging, unggas, telur, minyak, biji-bijian dan kacang-kacangan. Sedangkan asam lemak omega 3 bersumber dari hasil laut seperti salmon, ikan laut, kepiting, cumi-cumi, minyak ikan dan sayuran hijau. ${ }^{15,16}$ Konsumsi asam lemak omega 6 dan asam lemak omega 3 harus seimbang agar dapat memberikan manfaat untuk kesehatan. Pola konsumsi mengalami pergeseran dengan mengadopsi pola kosumsi dunia barat yaitu tinggi asam lemak omega 6 dan rendah asam lemak omega 3. Studi menyebutkan bahwa tingginya asupan asam lemak omega 6 dapat memblokir kerja asam lemak omega $3 .{ }^{16}$ Konsumsi tinggi asam lemak omega 6 dapat menghambat proses browing pada sel adiposa dengan menekan penggunaan trigliserida yang menyebabkan penumpukan simpanan trigliserida. Sedangkan asam lemak omega 3 mengurangi deposisi lemak pada jaringan adiposa dengan menekan lipogenik dan meningkatkan $\beta$-oksidasi. ${ }^{15-19}$ Oleh karena itu, penelitian ini bertujuan untuk mengetahui besar risiko asupan protein, serat, asam lemak omega 3 dan asam lemak omega 6 terhadap kejadian obesitas pada anak sekolah dasar di Semarang.

\section{METODE}

Penelitian ini merupakan penelitian observasional analitik dengan rancangan case control dan termasuk lingkup gizi masyarakat. Penelitian dilaksanakan di SDN Pekunden pada bulan FebruariMaret 2018. Skrining dilakukan pada 255 anak dan didapatkan sampel sebanyak 66 anak yang dibagi menjadi 2 kelompok yaitu: kelompok obesitas dan kelompok normal. Metode pengambilan sampel pada kelompok kasus dilakukan dengan metode simple random sampling dan kelompok kontrol dipilih oleh peneliti dengan melakukan matching berdasarkan usia dan jenis kelamin yang ditentukan dari kelompok kasus.

Kriteria inklusi subjek pada kelompok kasus dan kontrol yaitu subjek bersedia menjadi subjek penelitian dengan mengisi informed consent, subjek berusia 10-12 tahun, subjek sedang tidak menjalani program diet penurunan berat badan, subjek bersedia mengikuti penelitian sampai akhir, subjek dalam kondisi sehat dan tidak sedang dalam proses pengobatan. Perbedaan kriteria inklusi pada kelompok kasus dan kontrol yaitu pada kelompok kasus, subjek memiliki Indeks Massa Tubuh (IMT) obesitas pada $Z$-score IMT/U >2SD, sedangkan pada kelompok kontrol, subjek memiliki Indeks Massa Tubuh (IMT) normal pada Z-score IMT/U $\geq-2 \mathrm{SD}$ sampai dengan $\leq 1 \mathrm{SD}$. Sedangkan kriteria eksklusi yaitu subjek mengundurkan diri saat penelitian berlangsung, subjek sakit saat penelitian berlangsung, dan subjek pindah sekolah.

Variabel bebas dalam penelitian ini adalah asupan protein, asupan serat, asupan asam lemak omega 3 dan asupan asam lemak omega 6. Variabel terikat dalam penelitian ini adalah kejadian obesitas pada anak sekolah dasar. Sedangkan variabel perancu 
dalam penelitian ini adalah asupan energi, asupan karbohidrat, asupan lemak dan aktivitas fisik.

Data yang dikumpulkan dalam penelitian ini adalah data identitas subjek, data antropometri berat badan dan tinggi badan, data riwayat asupan dan data aktifitas fisik. Data berat badan subjek diperoleh dengan pengukuran langsung masing-masing dua kali pengukuran menggunakan timbangan injak digital dengan ketelitian $0,1 \mathrm{~kg}$ dan tinggi badan subjek diperoleh dengan pengukuran menggunakan mikrotoa dengan tingkat ketelitian $0,1 \mathrm{~cm}$, kemudian hasil pengukuran dirata-rata dan dihitung menggunakan WHO Antroplus dengan indikator Zscore $\geq-2 \mathrm{SD}$ sampai dengan $\leq 1 \mathrm{SD}$ untuk kriteria normal dan Z-score $>2 \mathrm{SD}$ untuk obesitas.

Data riwayat asupan diperoleh melalui wawancara langsung dengan subjek menggunakan formulir Semi Quantitative Food Frequency Questionnaire (SQ-FFQ) kemudian diolah menggunakan software Nutrisurvey. Setelah dianalisis, dibandingkan dengan kebutuhan masingmasing individu menggunakan rumus Nelson. Berdasarkan AKG 2013, cut off point asupan serat pada laki-laki usia 10-12 tahun sebesar 30 gr, dan perempuan usia 10-12 tahun sebesar 28 gr. Asupan asam lemak omega 3 pada laki-laki usia 10-12 tahun sebesar 1,2 gr dan pada perempuan usia 10-12 tahun sebesar 1 gr. Asupan asam lemak omega 6 pada lakilaki usia 10-12 tahun sebesar 12 gr dan perempuan usia 10-12 tahun sebesar 10 gr. Masing-masing asupan tergolong kurang apabila $<80 \%$, tergolong cukup apabila $80-100 \%$ dan tergolong lebih apabila $>100 \%$.

Data aktivitas fisik menggunakan The Physical Activity Questionnaire for Older Children (PAQ-C).
Penilaian aktivitas fisik dengan PAQ-C yaitu recall dalam 7 hari terakhir aktivitas fisik anak yang terdiri dari 9 soal dengan 5 poin, skor 1 untuk aktivitas fisik rendah dan skor 5 untuk aktivitas fisik tinggi. Total skor untuk kategori aktivitas fisik tinggi yaitu jika skor $\geq 27$ dan tergolong aktivitas fisik rendah jika skor $<27$.

Pengolahan dan analisis data dilakukan menggunakan program komputer. Analisis univariat digunakan untuk mendeskripsikan masing-masing variabel. Data diuji normalitasnya menggunakan uji Kolmogorov-Smirnov $\quad(\mathrm{n}>50) \quad$ dengan nilai kemaknaan $\mathrm{p}>0,05$. Analisis bivariat pada asupan protein, serat, asam lemak omega 3, asam lemak omega 6, energi, dan aktivitas fisik di uji menggunakan uji Chi-square sedangkan asupan karbohidrat dan lemak di uji menggunakan uji Fisher's untuk menganalisis besar risiko masingmasing variabel terhadap kejadian obesitas pada anak sekolah dasar.

\section{HASIL \\ Karakteristik Subjek Penelitian}

Jumlah subjek yang terlibat pada penelitian ini sebanyak 66 subjek yang terdiri dari 33 subjek pada masing-masing kelompok. Metode pengambilan sampel pada kelompok kasus dilakukan dengan metode simple random sampling. Sedangkan subjek kelompok kontrol dipilih oleh peneliti dengan melakukan matching usia dan jenis kelamin dari kelompok kasus yaitu 19 laki-laki dan 14 perempuan dengan rentang usia 10-12 tahun pada masing-masing kelompok. Karakteristik subjek selengkapnya dapat dilihat pada Tabel 1.

Tabel 1. Karakteristik Subjek Penelitian

\begin{tabular}{lcccccc}
\hline \multirow{2}{*}{ Variabel } & \multicolumn{3}{c}{ Obesitas $(\mathbf{n = 3 3 )}$} & \multicolumn{2}{c}{ Normal (n=33) } \\
\cline { 2 - 7 } & Mean \pm SD & Minimum & Maximum & Mean \pm SD & Minimum & Maximun \\
\hline Usia (tahun) & $10,5 \pm 0,66$ & 10 & 12 & $10,6 \pm 0,70$ & 10 & 12 \\
Kecukupan Zat Gizi & & & & & & \\
Protein (\%) & $100,7 \pm 23,48$ & 48,65 & 152,23 & $81,4 \pm 26,13$ & 44,93 & 163,62 \\
Serat (\%) & $75,3 \pm 25,20$ & 26,43 & 132,14 & $57,7 \pm 23,77$ & 21,67 & 99,33 \\
Omega 3 (\%) & $82,8 \pm 54,91$ & 30,83 & 326,00 & $73,8 \pm 15,94$ & 33,33 & 100,00 \\
Omega 6 (\%) & $159,6 \pm 43,49$ & 91,60 & 280,10 & $141,5 \pm 68,09$ & 81,58 & 364,17 \\
Energi (\%) & $93,1 \pm 15,20$ & 69,06 & 123,01 & $94,0 \pm 25,35$ & 53,37 & 155,98 \\
Karbohidrat (\%) & $69,0 \pm 17,47$ & 40,97 & 105,27 & $70,2 \pm 21,32$ & 39,89 & 111,39 \\
Lemak (\%) & $150,6 \pm 42,11$ & 80,71 & 243,05 & $162,4 \pm 52,87$ & 75,67 & 291,31 \\
Aktivitas Fisik & $29,2 \pm 5,47$ & 18,00 & 42,00 & $30,1 \pm 5,86$ & 22,00 & 46,00 \\
\hline
\end{tabular}

Tabel 1 menunjukkan karakteristik subjek penelitian pada kedua kelompok. Rerata kecukupan asupan protein, serat, asam lemak omega 3 dan asam lemak omega 6 pada kelompok obesitas lebih tinggi daripada kelompok normal. Sedangkan rerata kecukupan asupan energi, karbohidrat, lemak dan aktivitas fisik lebih rendah pada kelompok obesitas daripada kelompok normal.

Faktor Risiko Asupan Protein, Serat, Asam Lemak Omega 3, Asam Lemak Omega 6 dan Variabel Perancu dengan Kejadian Obesitas pada Anak Sekolah Dasar 
Tabel 2 menunjukkan gambaran variabel bebas dan variabel perancu terhadap kejadian obesitas. Asupan protein dan asam lemak omega 6 merupakan faktor risiko kejadian obesitas pada anak sekolah dasar, sedangkan asupan serat, asam lemak omega 3, energi, karbohidrat, lemak dan aktivitas fisik bukan merupakan faktor risiko kejadian obesitas pada anak sekolah dasar. Berdasarkan hasil penelitian, hasil menunjukkan bahwa terdapat 20 subjek $(71,4 \%)$ memiliki asupan protein berlebih pada kelompok obesitas dan subjek dengan asupan protein lebih memiliki faktor risiko 4,81 kali terjadinya obesitas. Terdapat 31 subjek $(56,4 \%)$ memiliki asupan asam lemak omega 6 berlebih pada kelompok obesitas dan subjek dengan asupan asam lemak omega 6 yang lebih memiliki faktor risiko sebesar 5,81 kali terjadinya obesitas.

Tabel. 2 Analisis Bivariat Hubungan Asupan Protein, Serat, Asam Lemak Omega 3, Asam Lemak Omega 6 dan Variabel Perancu dengan Kejadian Obesitas

\begin{tabular}{|c|c|c|c|c|c|c|}
\hline \multirow{2}{*}{ Variabel } & \multicolumn{2}{|c|}{ Obesitas $(n=33)$} & \multicolumn{2}{|c|}{ Normal $(n=33)$} & \multirow{2}{*}{$P$} & \multirow{2}{*}{ OR $(95 \% \mathrm{CI})$} \\
\hline & n & $\%$ & $\mathbf{n}$ & $\%$ & & \\
\hline $\begin{array}{l}\text { Asupan Protein } \\
\text { Lebih } \\
\text { Cukup }\end{array}$ & $\begin{array}{l}20 \\
13 \\
\end{array}$ & $\begin{array}{l}71,4 \% \\
34,2 \% \\
\end{array}$ & $\begin{array}{c}8 \\
25 \\
\end{array}$ & $\begin{array}{l}28,6 \% \\
65,8 \% \\
\end{array}$ & $003^{a^{0,}}$ & $\begin{array}{l}4,81(1,67- \\
13,86)\end{array}$ \\
\hline $\begin{array}{l}\text { Asupan Serat } \\
\text { Kurang } \\
\text { Cukup }\end{array}$ & $\begin{array}{l}23 \\
10\end{array}$ & $\begin{array}{l}51,1 \% \\
47,6 \%\end{array}$ & $\begin{array}{l}22 \\
11\end{array}$ & $\begin{array}{l}48,9 \% \\
52,4 \%\end{array}$ & $79^{a}$ & $\begin{array}{l}1,15(0,41- \\
3,24)\end{array}$ \\
\hline $\begin{array}{l}\text { Asupan Omega } 3 \\
\text { Kurang } \\
\text { Cukup }\end{array}$ & $\begin{array}{l}21 \\
12 \\
\end{array}$ & $\begin{array}{l}53,8 \% \\
44,4 \% \\
\end{array}$ & $\begin{array}{l}18 \\
15 \\
\end{array}$ & $\begin{array}{l}46,2 \% \\
55,6 \% \\
\end{array}$ & $46^{\mathrm{a}}$ & $\begin{array}{l}1,46(0,54- \\
3,91)\end{array}$ \\
\hline $\begin{array}{l}\text { Asupan Omega } 6 \\
\text { Lebih } \\
\text { Cukup }\end{array}$ & $\begin{array}{c}31 \\
2 \\
\end{array}$ & $\begin{array}{l}56,4 \% \\
18,2 \% \\
\end{array}$ & $\begin{array}{c}24 \\
9 \\
\end{array}$ & $\begin{array}{l}43,6 \% \\
81,8 \% \\
\end{array}$ & $02^{\mathrm{a}}$ & $\begin{array}{l}5,81(1,15- \\
29,44)\end{array}$ \\
\hline $\begin{array}{l}\text { Asupan Energi } \\
\text { Lebih } \\
\text { Cukup }\end{array}$ & $\begin{array}{c}9 \\
24 \\
\end{array}$ & $\begin{array}{l}40,9 \% \\
54,4 \% \\
\end{array}$ & $\begin{array}{l}13 \\
20 \\
\end{array}$ & $\begin{array}{l}59,1 \% \\
45,5 \% \\
\end{array}$ & $29^{a,}$ & $\begin{array}{l}0,58(0,20- \\
1,63)\end{array}$ \\
\hline $\begin{array}{c}\text { Asupan } \\
\text { Karbohidrat } \\
\text { Lebih } \\
\text { Cukup } \\
\end{array}$ & $\begin{array}{c}2 \\
31\end{array}$ & $\begin{array}{l}66,7 \% \\
49,2 \%\end{array}$ & $\begin{array}{c}1 \\
32\end{array}$ & $\begin{array}{l}33,3 \% \\
50,8 \%\end{array}$ & $1^{\mathrm{b}}$ & $\begin{array}{l}2,06(0,18- \\
23,94)\end{array}$ \\
\hline $\begin{array}{l}\text { Asupan Lemak } \\
\text { Lebih } \\
\text { Cukup }\end{array}$ & $\begin{array}{c}30 \\
3 \\
\end{array}$ & $\begin{array}{l}51,7 \% \\
37,5 \% \\
\end{array}$ & $\begin{array}{c}28 \\
5 \\
\end{array}$ & $\begin{array}{l}48,3 \% \\
62,5 \% \\
\end{array}$ & $71^{\mathrm{b}}$ & $\begin{array}{l}1,79(0,39- \\
8,17)\end{array}$ \\
\hline $\begin{array}{l}\text { Aktivitas Fisik } \\
\text { Tinggi } \\
\text { Rendah }\end{array}$ & $\begin{array}{l}20 \\
13 \\
\end{array}$ & $\begin{array}{l}47,6 \% \\
54,2 \%\end{array}$ & $\begin{array}{l}22 \\
11 \\
\end{array}$ & $\begin{array}{l}52,4 \% \\
45,8 \%\end{array}$ & $61^{\mathrm{a}}$ & $\begin{array}{l}0,77(0,28- \\
2,10)\end{array}$ \\
\hline
\end{tabular}

$p=p$ value, $O R=$ Odds Ratio, $C I=$ Confidance Interval, ${ }^{a}$ Chi-Square, ${ }^{b}$ Fisher's Exact

\section{PEMBAHASAN}

Obesitas yang terjadi pada masa anak-anak merupakan masalah yang serius karena prevalensi terus meningkat baik di negara maju maupun di negara berkembang. ${ }^{20}$ Obesitas pada anak usia 6-12 tahun dapat berlanjut hingga usia dewasa dan dapat menimbulkan risiko penyakit degeneratif. ${ }^{2,3}$ Penelitian yang pernah dilakukan di Semarang pada Tahun 2016 menyebutkan dari 149 anak sekolah dasar yang di skrining, 24,7\% diantaranya mengalami obesitas. Sedangkan pada hasil penelitian ini, dari 255 anak usia 10-12 tahun di SDN Pekunden Semarang didapatkan 41 anak $(16,08 \%)$ mengalami obesitas. Hasil penelitian menunjukkan bahwa terdapat hubungan antara asupan protein dan asam lemak omega 6 dengan kejadian obesitas pada anak sekolah dasar di Semarang. Sedangkan asupan serat, asam lemak omega 3 dan variabel perancu (energi, karbohidrat, lemak dan aktivitas fisik) tidak menunjukkan adanya hubungan terhadap kejadian obesitas pada anak sekolah dasar di Semarang.

Protein merupakan zat gizi yang sangat penting, karena berhubungan erat dengan prosesproses kehidupan seperti pertumbuhan, pengangkut dan penyimpanan zat gizi, pembentukan antibodi dan sumber energi. ${ }^{21}$ Berdasarkan hasil penelitian, asupan protein berhubungan dengan kejadian obesitas pada anak sekolah dasar. Persentase asupan protein pada kelompok obesitas memiliki rerata kecukupan lebih tinggi dibandingkan dengan kelompok normal. Sumber makanan tinggi protein yang dikonsumsi anak-anak seperti telur ayam, daging ayam, daging kambing, daging sapi, ikan, udang, sarden, tahu dan tempe. Hasil penelitian ini sejalan dengan penelitian yang dilakukan oleh Maria et al di Italia menyatakan bahwa terdapat hubungan asupan protein dengan kejadian obesitas pada anak sekolah dasar $(p=0,01)$. Berdasarkan penelitian tersebut, persentase kecukupan protein dan asupan protein pada kelompok 
anak obesitas usia 9-13 tahun lebih tinggi dibandingkan dengan kelompok anak normal. Berdasarkan hasil penelitian, anak sekolah dasar cenderung memiliki nafsu makan yang meningkat karena tubuh membutuhkan persiapan untuk fase tumbuh kembang dan kecenderungan anak-anak mengganti sayuran dengan lauk dari sumber protein hewani maupun nabati pada saat makan. Oleh karena itu anak cenderung memiliki asupan serat yang kurang dan asupan protein yang tinggi.

Konsumsi protein dalam jumlah berlebih, protein sel akan dipecah menjadi asam amino untuk dijadikan energi atau disimpan dalam bentuk lemak. Protein dapat digunakan sebagai sumber energi setelah mengalami proses deaminasi di hati, yaitu proses hidrolisis asam amino menjadi asam keto dan ammonia $\left(\mathrm{NH}_{4}^{+}\right)$. Lalu, asam amino akan memasuki siklus krebs untuk diubah menjadi asetil Ko-A. Konsumsi protein dalam jumlah berlebih, asetil KoA yang terbentuk akan dipakai untuk menghasilkan asam lemak yang berperan dalam pembentukan selsel adiposa. Hal inilah yang menyebabkan kenaikan jaringan lemak yang berimbas pada kenaikan berat badan dan akhirnya terjadi obesitas. ${ }^{12}$

Asam lemak omega 6 termasuk salah satu asam lemak esensial yang tidak bisa didapatkan oleh tubuh baik dari asam lemak lain maupun dari karbohidrat ataupun asam amino. Asam lemak esensial terdiri dari asam linoleat (AL), asam linolenat (ALN) serta asam arakidonat (AA). ${ }^{17,18}$ Asam lemak omega 6 juga menjadi faktor risiko terjadiya obesitas apabila dikonsumsi secara berlebihan. Berdasarkan penelitian yang dilakukan, asam lemak omega 6 memiliki hubungan terhadap kejadian obesitas pada anak sekolah dasar di Semarang $(p=0,02)$. Rerata kecukupan asam lemak omega 6 pada kelompok obesitas lebih tinggi dari kelompok normal. Hal tersebut karena anak-anak mengkonsumsi makanan tinggi asam lemak omega 6 seperti sumber daging, ikan dan hasil laut, kacang-kacangan, serta margarin ataupun minyak goreng yang digunakan untuk memasak dirumah.

Asam lemak omega 6 yang dikonsumsi berlebih memiliki efek pada kenaikan berat badan melalui mekanisme adipogenesis. Berdasarkan mekanisme adipogenesis, tingginya asam arakidonat melaui reseptor PI2 mengaktifkan cAMP protein kinase A, memberikan sinyal proliferasi dan diferensiasi pada jaringan adiposa putih untuk mencegah terjadinya proses browning pada jaringan adiposa dengan menekan penggunaan trigliserida yang menyebabkan penumpukan simpanan trigliserida. Sehingga, konsumsi asam lemak omega 6 dalam jumlah berlebih dapat menjurus pada penyakit degeneratif dikemudian hari, seperti obesitas. ${ }^{15-19}$
Serat merupakan polisakarida yang terdapat pada tumbuhan yang tidak dapat dicerna oleh enzim pencernaan. Asupan serat yang cukup dapat mencegah kejadian obesitas., ${ }^{9} 13$ Hasil penelitian menunjukkan tidak ada hubungan antara asupan serat dengan kejadian obesitas pada anak sekolah dasar di Semarang. Di Indonesia, hasil penelitian tersebut juga sejalan dengan penelitian yang dilakukan oleh Sari di Padang, yaitu asupan serat tidak berhubungan dengan kejadian obesitas pada anak sekolah dasar $(p=0,677)$. Penelitian yang dilakukan oleh Puchau et al di Spanyol memiliki hasil yang berbeda yaitu asupan serat berhubungan dengan kejadian obesitas pada anak sekolah $(p=0,025)$. Hal ini disebabkan dari jumlah subjek pada penelitian yang dilakukan di Semarang ini lebih sedikit $(n=66)$ jika dibandingkan penelitian yang dilakukan di Spanyol $(n=369)$ dengan desain penelitian yang sama menggunakan case control study.

Asupan serat dalam penelitian ini tidak berhubungan dengan kejadian obesitas dikarenakan asupan serat rendah dan asupan lemak tinggi. Serat dapat mengikat asam empedu dan membentuk misel yang akan dikeluarkan melalui feses. Apabila seseorang memiliki asupan serat kurang, maka asam empedu akan memecah lemak dan diabsorbsi oleh usus halus. Pemecahan lemak menghasilkan asam lemak dan gliserol, dimana asam lemak dan gliserol adalah komponen penyusun trigliserida. Sehingga rendahnya serat dapat menyebabkan penumpukan trigliserida yang dapat menyebabkan obesitas. ${ }^{20}$ Rendahnya konsumsi asupan serat dikarenakan anakanak tidak menyukai makanan sumber serat seperti buah dan sayuran. Berdasarkan hasil data survei konsumsi makanan, kurangnya konsumsi buah dan sayur pada anak usia 5-12 tahun sebesar 96,5\%. ${ }^{8}$ Rendahnya konsumsi buah dan sayuran karena anakanak cenderung memilih suatu makanan tertentu. Setiap individu memiliki ketertarikan pada makanan berdasarkan selera dan rasa. Pada anak-anak sebagian besar memilih makanan berdasarkan pada rasa makanan dan anak-anak cederung menyukai rasa manis. Sedangkan rasa pahit yang mendominasi pada sayuran membuat anak tidak menyukai rasa dari sayuran yang dapat menyebabkan rendahnya konsumsi serta daya terima terhadap sayuran. ${ }^{21}$

Asam lemak omega 3 merupakan asam lemak esensial yang tidak dapat diperoleh dari tubuh, melainkan harus didapatkan langsung dari makanan. Adapun 3 bentuk omega 3 yaitu: asam alfa linolenat (LNA), eikosapentaenoat (EPA) serta dokosaheksaenoat (DHA). Hasil penelitian menunjukkan tidak ada hubungan antara asupan asam lemak omega 3 dengan kejadian obesitas pada anak sekolah dasar. Penelitian Floyd et al di Amerika menyatakan bahwa tidak ada hubungan $(p=0,074)$ 
antara asupan asam lemak omega 3 pada anak usia sekolah. Hasil penelitian tidak menunjukkan adanya hubungan asupan asam lemak omega 3 dengan kejadian obesitas dikarenakan dalam penelitian ini asupan asam lemak omega 6 juga tinggi. Konsumsi asam lemak omega 6 dan omega 3 harus seimbang agar dapat memberikan manfaat untuk kesehatan. Studi menyebutkan bahwa tingginya asupan asam lemak omega 6 dapat memblokir kerja asam lemak omega $3 .{ }^{16}$ Asam lemak omega 6 dapat meningkatkan trigliserida seluler dengan meningkatkan permeabilitas membran. Sedangkan asam lemak omega 3 mengurangi deposisi lemak pada jaringan adiposa dengan menekan lipogenik dan meningkatkan $\beta$-oksidasi. ${ }^{15-19}$

Asupan energi, karbohidrat dan lemak dalam penelitian ini tidak menunjukkan adanya hubungan terhadap kejadian obesitas. Hasil penelitian ini sejalan dengan penelitian yang dilakukan oleh Mumena et al di Karibia yang menunjukkan tidak ada hubungan antara asupan energi dengan kejadian obesitas pada anak usia 6-10 tahun $(p=0,628)$, penelitian yang dilakukan oleh Dimitrios et al di Yunani Utara bahwa asupan karbohidrat tidak berhubungan dengan anak sekolah dasar obesitas usia 9-12 tahun $(p=0,341)$ dan pada penelitian yang dilakukan Syahrul et al pada anak usia 6-12 tahun di Makassar, bahwa tidak terdapat hubungan yang signifikan $(p=0,085)$ antara asupan lemak dengan kejadian obesitas. Aktivitas fisik dalam penelitian ini menunjukkan tidak ada hubungan dengan kejadian obesitas pada anak sekolah dasar. Berdasarkan hasil penelitian, sebagian besar aktivitas fisik pada anak obesitas dan normal termasuk kategori tinggi yaitu $\geq 27$ menggunakan kuesioner aktivitas fisik PAQ-C. Berdasarkan penelitian yang dilakukan oleh Shoo et al menyatakan bahwa penelitian yang dilakukan di Malaysia pada anak obesitas usia 7-12 tahun menggunakan kuesioner aktivitas fisik PAQ-C tidak berhubungan dengan indeks masa tubuh. Hal ini dikarenakan aktivitas yang dilakukan anak-anak pada saat di sekolah, di rumah maupun pada waktu luang adalah jenis aktivitas yang dilakukan sehari-hari. Sehingga pada kelompok anak obesitas maupun normal cenderung memiliki jenis dan frekuensi aktivitas fisik yang sama.

Hasil penelitian menunjukkan bahwa pada faktor perancu tidak menujukkan adanya hubungan terhadap kejadian obesitas pada anak sekolah dasar. Berdasarkan hasil penelitian, anak dengan IMT normal memiliki asupan yang berlebih dan aktivitas fisik yang berlebih. Hal tersebut dapat disebabkan oleh tingkat metabolisme tubuh yang tinggi yang berasal dari faktor genetik. Proses metabolisme pada masing-masing anak berbeda. Tingginya metabolisme dalam tubuh menjadikan anak dapat mengkonsumsi banyak makanan tanpa takut untuk menjadi gemuk meskipun memiliki aktifitas fisik yang tinggi. ${ }^{23}$

\section{SIMPULAN}

Hasil penelitian menunjukkan bahwa asupan protein berlebih memiliki risiko 4,81 kali lebih besar dan asupan asam lemak omega 6 berlebih berisiko 5,81 kali lebih besar terhadap kejadian obesitas pada anak sekolah dasar. Sedangkan asupan serat dan asam lemak omega 3 dalam penelitian ini bukan merupakan faktor risiko kejadian obesitas pada anak sekolah dasar.

\section{SARAN}

Orang tua diharapkan mengetahui bahayanya asupan protein dan asam lemak omega 6 jika dikonsumsi secara berlebihan, oleh karena itu orang tua harus mengetahui sumber makanan protein dan asam lemak omega 6 untuk memberikan variasi makanan pada anak agar tidak mengkonsumsi secara berlebihan. Orang tua hendaknya juga mengetahui pentingnya asupan serat dan asam lemak omega 3, sehingga asupan tersebut dapat sesuai dengan kebutuhan anak.

\section{UCAPAN TERIMAKASIH}

Puji dan syukur penulis panjatkan kehadirat Allah SWT atas segala rahmat dan karunia yang telah diberikan kepada penulis. Terimakasih kepada Bapak, Ibu dan keluarga yang selalu memberikan do'a dan dukungan. Terimakasih kepada dosen pembimbing dan dosen penguji atas saran dan ilmu yang diberikan kepada penulis. Terimakasih juga kepada seluruh responden, teman-teman enumerator dan semua pihak yang telah membantu dan memberikan dukungan dalam penelitian ini.

\section{DAFTAR PUSTAKA}

1. Vasquez FD , Corvalan CL, Uauy RE, Kain JA. Anthropometric indicators as predictors of total body fat and cardiometabolic risk factors in Chilean children at 4, 7 and 10 years of age. European Journal of Clinical Nutrition. 2017. 71: 536-543.

2. Rathnayake KM, Satchithananthan A, Mahamithawa S, Jayawardena R. Early life predictors of preschool overweight and obesity: a case-control study in Sri Lanka. BioMed Central Public Health. 2013;13(1):1.

3. Kementerian Kesehatan RI. Pedoman Pencegahan dan Penanggulangan Kegemukan dan Obesitas pada Anak Sekolah. Jakarta: Kementerian Kesehatan RI Direktorat Jenderal Bina Gizi dan Kesehatan Ibu dan Anak; 2012. 
4. Riset Kesehatan Dasar. Badan Penelitian dan Pengembangan Kesehatan Republik Indonesia. 2013.

5. Riset Kesehatan Dasar. Badan Penelitian dan Pengembangan Kesehatan Republik Indonesia. 2010.

6. Puspasari I, Sulchan M, Widyastuti N. Sedentary Lifestyle Sebagai Faktor Risiko Terhadap Kejadian Obesitas Anak Stunted Usia 9-12 Tahun Di Kota Semarang. Journal Of Nutrition College. 2017; 6(4): 307-312.

7. Badan Penelitian dan Pengembangan Kesehatan. Survei Konsumsi Makanan Individu dalam Buku Survei Diet Total Indonesia 2014: Laporan Nasional. Jakarta: Badan Penelitian dan Pengembangan Kesehatan;2014.

8. Hermina, Prihatini S. Gambaran Konsumsi Sayur dan Buah Penduduk Indonesia dalam Konteks Gizi Seimbang. Pusat Penelitian dan Pengembangan Upaya Kesehatan Masyarakat. 2014.p. 212.

9. Huang JY, Qi SJ. Childhood Obesity and Food Intake. World Journal Pediatric. 2015;11(2):102.

10. Hornell A, Lagstrom H, Lande B, Thorsdottir I. Protein Intake From 0 to 18 years Of Age and It's Relation to Health: a systematic literature review for the 5th Nordic Nutrition Recommendations. Food Nutrition Research. 2013;57(1):1-4.

11. Champe PC, Harvey RA, Ferrier DR. Biochemistry3rd Edition. Jakarta: Penerbit Buku Kedokteran EGC;2010. p. 272-279.

12. Brosnan ME, Brosnan JT, Young VR. Protein. In: Lanham SA, Macdonald IA, Roche HM, editors. Nutrition and Metabolism; The Nutrition Society Textbook Series 2nd edition. Germany: WilleyBlackwell; 2011. p. 72.

13. Anderson JW, Baird P, Davis RH, Ferreri S, Knudtson M, Koraym A, et al. Health Benefits of Dietary Fiber. Nutrition Reviews. 2009;67(4):188-205.

14. Du H, Van Der A DL, Boshuizen HC, Forouhi NG, Wareham NJ, Halkjaer J et al. Dietary Fiber and Subsequent Changes in Body Weight and
Waist Circumference in European Men and Women.American Journal Of Clinical Nutrition. 2010;91:329-336.

15. Simopoulos AP. An increase in the Omega6/Omega-3 fatty acid ratio increases the risk for obesity. Nutrients. 2016; 8(3): 1-17.

16. Candela CG, Bermejo LM, Kohen VL. Importance of a balanced omega 6/omega 3 ratio for the maintenance of health. Nutritional recommendations. Nutrition Hospital. 2011;26(2):323-324.

17. Simopoulos AP. Evolutionary aspects of diet, the omega-6/omega-3 ratio and genetic variation: nutritional implications for chronic diseases. Biomedicine and Pharmacotherapy Journal. 2006;60: 502-507.

18. Simopoulos AP, Dinicolantonio JJ. The importance of a balance omega- 6 to omega 3 ratio in the prevention and management of obesity. British Medical Journal. 2016;3:1-6.

19. Cebrian SL, Costa AGV, Carretero SN, Zabala M, Martinez JA, Aliaga MJM. Role of omega-3 fatty acids in obesity, metabolic syndrome, and cardiovascular diseases: a review of the evidence. Journal Physiology Biochemistry. 2013; 69:633651.

20. Lattimer JM, Haub MD. Effects of Dietary Fiber and Its Components On Metabolic Health. Departmet of Human Nutrition. Kansas State University. 2010; 2: 1266-1289.

21. Silventoinen K, Sans S, Tolonen H, Monterde D, Kuulasmaa K, Kesteloot H, et al. Trends in obesity and energy supply in the WHO MONICA Project. International Journal Obesity Related Metabolic Disorder 2004;28:710-718.

22. Song K, Lee H. Association between the Number of Unfamiliar Vegetables and Dietary Factors of Elementary School Children. The Korean Society of Food Science and Nutrition. 2013; 18(4):280286.

23. Irawan, M. Anwari. Metabolisme Energi Tubuh \& Olahraga. Polton Sports Science \& Performance Lab Brief; 2007:7(1). p. 1-9. 